\title{
ПОРУШЕННЯ МЕНСТРУАЛЬНОГО ЦИКЛУ У ЖІНОК, ЩО ХВОРІЮТЬ НА ТУБЕРКУЛЬОЗ
}

Ковельський медичний коледж

Резюме. У статті наведені дані щодо стану репродуктивної функції у жінок, що хворіють на туберкульоз легень. У даної когорти хворих визначено високий рівень порушень менструального циклу $(67,4$ \%). Встановлено, що чинниками ризику виникнення порушень менструальної функції у жінок, хворих на туберкульоз легень, є пізнє менархе, наявність інфекцій, що передаються статевим шляхом, ендокринна патологія тощо.
Показано, що туберкульозний процес будь-якої локалізації чинить несприятливу дію на органи репродуктивної системи у жінок, а ступінь проявів порушень залежить від активності та поширення туберкульозу.

Ключові слова: менструальний цикл, туберкульоз, репродуктивна система.

Матеріал і методи. Проведено клінічнолабораторне обстеження 48 пацієнток репродуктивного віку, хворих на вперше виявлений туберкульоз легень (основна група) та 30 здорових жінок (контрольна група). Репродуктивну функцію пацієнток вивчали загальноприйнятими в гінекології методами діагностики: анамнезу захворювання, клінічно-лабораторних методів, гормонального та інструментального обстеження. Середній вік пацієнток склав $31,2 \pm 2,1$ року.

Результати дослідження та їх обговорення. Результати досліджень показали, що із 48 пацієнток основної групи 26 (54 \%) осіб хворі на вперше виявлений дисемінований туберкульоз, 13 (27,0 \%) - на фіброзно-кавернозний і дев'ять $(18,7$ \%) осіб на вогнищевий. Загалом рівень порушень репродуктивної функції серед жінок, що хворіють на туберкульоз легень, становив 67,4\%.

Нормальний менструальний цикл відмічали в 19 пацієнток (39,5 \%) основної групи. Порушення МЦ різного характеру спостерігали у 29 $(60,4 \%)$ жінок основної групи за різних форм туберкульозу. Комплексна оцінка даних анамнезу показала, що в більшості пацієнток мало місце пізнє менархе - у 21 (43,7 \%) жінок. Значно частіше жінки основної групи вказували на несприятливий перебіг вагітності та пологів, частота невиношування вагітності в ранньому терміні склала 19 (39,5 \%) проти контролю - у 4 (13,3\%). За вогнищевого туберкульозу в пацієнток мали місце ПМЦ у чотирьох осіб. Функціональні порушення репродуктивної функції проявлялися дисменореєю у 15 (31,2 \%) жінок; в 11 (22,9 \%) гіперполіменореєю, альгодисменореєю - у 10 (20,8 \%), опсоменореєю - у 9 (18,7 \%) та аменореєю - у 3 (6,2 \%).

Результати досліджень гормональної функції показали, що характер перебігу туберкульозу та ступінь туберкульозної інтоксикації негативно впливають на стан гіпоталамо-гіпофізарнояєчникової системи: у жінок, хворих на інфільтративний туберкульоз легень, рівень фолікулостимулювального гормону (ФСГ) сягав до $13,2 \pm 1,21 \mathrm{MO} /$ мл, проти 9,6 $\pm 1,12 \mathrm{MO} /$ мл у конт-

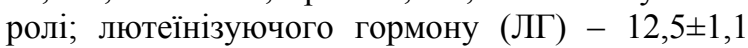


Таблиця 1

Гормональний гомеостаз паціснток, хворих на туберкульоз легень

\begin{tabular}{|c|c|c|}
\hline Гормони & Основна група $(\mathrm{n}=25)$ & Контролна група $(\mathrm{n}=20)$ \\
\hline ФСГ (МО/мл) & $13,2 \pm 1,21$ & $9,6 \pm 1,12$ \\
\hline ЛГ (МО/мл) & $12,5 \pm 1,1$ & $8,5 \pm 1,3$ \\
\hline Е (ПГ/мл) & $98,3 \pm 6,2$ & $76,3 \pm 4,1$ \\
\hline Пг (нмоль/л) & $21,4 \pm 3,4$ & $16,9 \pm 2,7$ \\
\hline
\end{tabular}

Таблиця 2

Порушення репродуктивної функції жінок, що хворіють на туберкульоз легень

\begin{tabular}{|c|c|c|c|}
\hline $\begin{array}{l}\text { Діагностичні } \\
\text { критерії }\end{array}$ & $\begin{array}{l}\text { Дисемінований } \\
\text { туберкульоз }\end{array}$ & $\begin{array}{c}\text { Фіброзно-кавернозний } \\
\text { туберкульоз }\end{array}$ & Вогнищевий туберкульоз \\
\hline Менструальний цикл & $\begin{array}{c}\text { Порушення } \\
\text { менструального циклу, } \\
\text { схильність до } \\
\text { гіперполіменореї }\end{array}$ & $\begin{array}{c}\text { Порушення менстру- } \\
\text { ального циклу, } \\
\text { схильність до } \\
\text { альгодисменореї }\end{array}$ & $\begin{array}{c}\text { Нормальний } \\
\text { менструальний цикл або } \\
\text { схильність до } \\
\text { альгодисменореї }\end{array}$ \\
\hline $\begin{array}{l}\text { Порушення репро- } \\
\text { дуктивної функції }\end{array}$ & $\begin{array}{c}\text { Переважно вторинне } \\
\text { безпліддя }\end{array}$ & $\begin{array}{c}\text { Первинне безпліддя в } \\
\text { поєднанні з супутньою } \\
\text { гінекологічною } \\
\text { патологією } \\
\end{array}$ & $\begin{array}{c}\text { Безпліддя не } \\
\text { прослідковується }\end{array}$ \\
\hline $\begin{array}{c}\text { Ускладнення вагітності та } \\
\text { пологів }\end{array}$ & $\begin{array}{c}\text { Невиношування, викидні, } \\
\text { передчасні пологи }\end{array}$ & $\begin{array}{c}\text { Невиношування, передча- } \\
\text { сні пологи, мертвонаро- } \\
\text { дження }\end{array}$ & $\begin{array}{c}\text { Загроза викидня, загроза } \\
\text { передчасних пологів, } \\
\text { післяпологові } \\
\text { ускладнення }\end{array}$ \\
\hline Гормональний гомеостаз & $\begin{array}{c}\text { Абсолютна та відносна } \\
\text { естрогенія }\end{array}$ & $\begin{array}{c}\text { Абсолютна та відносна } \\
\text { естрогенія }\end{array}$ & Відносна естрогенія \\
\hline Функціональні зміни & $\begin{array}{c}\text { Недостатність люте- } \\
\text { їнової фази, ановуляція, } \\
\text { схильність до гіперплазій }\end{array}$ & $\begin{array}{c}\text { Недостатність люте- } \\
\text { їнової фази, ановуляція }\end{array}$ & $\begin{array}{c}\text { Недостатність лютеїнової } \\
\text { фази }\end{array}$ \\
\hline
\end{tabular}

MO/мл, проти $8,5 \pm 1,3$ у контролі; естрадіолу (Е) $98,3 \pm 6,2$ Пг/мл, проти 76,3 $\pm 4,1$ у контролі і проге-

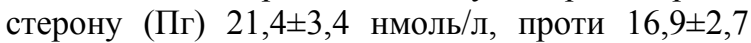
нмоль/л у контролі (табл. 1). Загалом за наявності туберкульозу легень порушення МЦ у більшій мірі визначалися гіперестрогенемією.

Ретроспективний аналіз захворюваності на туберкульоз у жінок та дані акушерськогінекологічного анамнезу впродовж лікування туберкульозу дозволили встановити тенденцію щодо порушень репродуктивної функції у жінок, залежно від форми туберкульозного ураження.

Пацієнтки, хворі на дисемінований туберкульоз легень, переважно схильні до гіперполіменорей на тлі абсолютної та відносної естрогенії, 3 недостатністю лютеїнової фази МЦ та ускладненим паритетом: тенденцією до невиношування та вторинного безпліддя, а також схильністю до проліферативних змін ендометрія із супутньою гормонально залежною гінекологічною патологією.

У жінок, що хворіють на фібрознокавернозний туберкульоз легень, переважно спостерігають порушення МЦ за типом альгодисменореї, часто мають місце ановуляторні цикли, визначається абсолютна або відносна естрогенія та недостатність лютеїнової фази. На цьому тлі виникають порушення та ускладнення репродуктивної функції.
Вогнищевий туберкульоз легень без ознак інтоксикації не сприяє порушенням МЦ у жінок. У пацієнток із вогнищевим туберкульозом переважно спостерігається недостатність лютеїнової фази, відносна естрогенія тощо (табл. 2).

Супутня гінекологічна патологія мала місце у 21 (43,7 \%) пацієнтки, хворих на туберкульоз легень, і представлена: міомою матки - у 6 (12,5 \%) осіб, ерозією шийки матки - у 12 (25\%), ендоцервіцитом - у 3 (6,2 \%). У групі контролю ендоцервіцит спостерігали у двох жінок (6,6 \%) та в однієї пацієнтки - фіброматоз (2,0 \%).

У процесі обстеження пацієнток, що хворіють на туберкульоз легень, у структурі гінекологічної патології виявлено запальні захворювання зовнішніх і внутрішніх статевих органів у 31,7 \% осіб, що також сприяє порушенням МЦ у даної категорії пацієнток.

Таким чином, вперше виявлений туберкульоз легень у жінок репродуктивного віку є вагомим чинником ризику розвитку порушень МЦ. Застосування протитуберкульозних препаратів, інтоксикація, зниження імунної реактивності організму та детоксикаційної функції печінки, що має місце в кожної другої пацієнтки, вимагає проведення гормональної корекції з урахуванням вищезазначених чинників ризику. 


\section{Висновки}

1. Прогноз щодо порушень менструального циклу у жінок, хворих на туберкульоз легень, зумовлений активністю специфічного процесу та ступенем туберкульозної інтоксикації.

2. Пацієнткам, хворим на туберкульоз легень, впродовж лікування специфічного процесу рекомендована індивідуальна гормональна корекція порушень менструального циклу, направлена на відновлення репродуктивної системи.

Перспективи подальших досліджень. Проблема порушень менструального циклу у жінок, що хворіють на туберкульоз легень, вимагає комплексного вивчення стану ендометрія, що буде представлено в наступних наукових роботах.

\section{Література}

1. Грабарник А.Е. Особенности бактериального пейзажа влагалища у женщин больных туберкулезом / А.Е. Грабарник, О.Г. Жученко, И.С. Курносова // Туберкулез и болезни легких. - 2011. - № 4. - С. 108.

2. Жученко О.Г. Репродуктивное здоровье женщин при туберкулезе / О.Г. Жученко, А.Е. Грабарник, И.С. Курносова // Туберкулез и болезни легких. 2011. - № 4. - С. 146.

3. Жученко О.Г. Репродуктивное здоровье женщин с легочным и урогенитальным туберкулезом / О.Г. Жу- ченко, В.Е. Радзинский // Пробл. туберкулеза и болезней легких. - 2004. - № 7. - С. 58-62.

4. Запорожан В.М. Репродуктивне здоров'я жінок в умовах епідемії туберкульозу / В.M. Запорожан, С.П. Польова, Ю.І. Бажора // Ж. Акад. мед. наук України. - 2007. - Т. 13, № 4. - С. 734-742.

5. Иванов А.Г. Распространенность и прогнозирование факторов риска нарушений репродуктивной функции женщин / А.Г. Иванов // Казан. мед. ж. - 2004. - Т. 85, № 6. - С. 415-418.

6. Каюкова С.И. Выявление заболеваний репродуктивной системы у женщин, больных туберкулезом органов дыхания / С.И. Каюкова // Туберкулез и болезни легких. - 2011. - № 4. - С. 187.

7. Клічук Р.В. Клінічно-морфологічні зміни репродуктивної системи у жінок, хворих на туберкульоз / Р.В. Клічук, С.П. Польова // Досягнення біол. та мед. 2011. - № 2 (18). - С. 69-71.

8. Клічук Р.В. Ультразвукова діагностика порушень фертильності у жінок, хворих на туберкульоз легень / Р.В. Клічук, С.П. Польова, Т.О. Коцур // ПАГ. - 2012. - № 2 (450). - C. 92-94.

9. Клічук Р.В. Чинники ризику розвитку туберкульозу у жінок репродуктивного віку / Р.В. Клічук, С.П. Польова // Одес. мед. ж. -2012 . - № 1 (129). - С. 38-40.

10. Корандо Н.В. Діагностика стану ендометрія у жінок, хворих на туберкульоз, в період прегравідарної підготовки / Н.В. Корандо, С.П. Польова, А.В. Семеняк // Клін. анатом. та операт. хірургія. -2011 . - Т. 10, № 1. - C. 44-46.

\section{НАРУШЕНИЯ МЕНСТРУАЛЬНОГО ЦИКЛА У ЖЕНЩИН, БОЛЕЮЩИХ ТУБЕРКУЛЕЗОМ}

\section{О.в. Романюк}

Резюме. В статье приведены данные о состоянии репродуктивной функции у женщин, болеющих туберкулезом легких. В данной категории больных определяется высокий уровень нарушений менструального цикла $(67,4$ \%). Установлено, что факторами риска возникновения нарушений менструального цикла у женщин, болеющих туберкулезом легких, являются позднее менархе, наличие инфекций, эндокринная патология. Показано, что туберкулезный процесс любой локализации отрицательно влияет на органы репродуктивной системы у женщин, а степень их нарушений зависит от активности и распостраненности туберкулеза.

Ключевые слова: менструальный цикл, туберкулез, репродуктивная система.

\section{MENSTRUAL IRREGULARITIES IN WOMEN WITH TUBERCULOSIS}

\section{O.V. Romaniuk}

Abstract. The article presents data on the state of reproductive function in women suffering from tuberculosis. In this cohort of patients a high level of menstrual disorders $(67,4 \%)$ is diagnosed. It was established that delayed menarche, the presence of infections, sexually transmitted diseases, endocrine pathology, etc. are the risk factors of menstrual dysfunction in women with tuberculosis. It is shown that tuberculosis process in any location has an adverse influence on the reproductive system in women, and the degree of manifestation of disorders depends on the activity and the spread of tuberculosis.

Key words: menstrual cycle, tuberculosis, reproductive system.

Medical College (Kovel)

Рецензент - д. мед. н. І.В. Каліновська
Buk. Med. Herald. - 2016. - Vol. 20, № 1 (77). - P. 141-143

Надійшла до редакції 15.12.2015 року

(C) О.В. Романюк, 2016 